Spring 2000

\title{
Convents as Litigants: Dowry and Inheritance Disputes in Early- Modern Spain
}

Elizabeth Lehfeldt

Cleveland State University, e.lehfeldt@csuohio.edu

Follow this and additional works at: https://engagedscholarship.csuohio.edu/clhist_facpub

Part of the History Commons

How does access to this work benefit you? Let us know!

Publisher's Statement

Copyright 2000 Carnegie Mellon University Press. Available on publisher's site at

http://www.jstor.org/stable/3789215.

\section{Original Citation}

Lehfeldt, Elizabeth A. 2000. "Convents As Litigants: Dowry and Inheritance Disputes in Early-Modern Spain". Journal of Social History. 33, no. 3: 645-664.

\section{Repository Citation}

Lehfeldt, Elizabeth, "Convents as Litigants: Dowry and Inheritance Disputes in Early-Modern Spain" (2000). History Faculty Publications. 3.

https://engagedscholarship.csuohio.edu/clhist_facpub/3

This Article is brought to you for free and open access by the History Department at EngagedScholarship@CSU. It has been accepted for inclusion in History Faculty Publications by an authorized administrator of EngagedScholarship@CSU. For more information, please contact library.es@csuohio.edu. 


\title{
CONVENTS AS LITIGANTS: DOWRY AND INHERITANCE DISPUTES IN EARLY-MODERN SPAIN
}

\author{
By Elizabeth A. Lehfeldt
}

Cleveland State University

In 1631 Gómez de Mendoza Manrique appeared in court to oppose his sister, Inés de Velasco, a nun in the convent of Santa María de las Huelgas in Valladolid, Spain. Inés and the convent had filed a lawsuit to force Gómez to pay Inés' yearly maintenance allowance. In the course of the trial Gómez revealed that he was shouldering an immense burden on behalf of female monasticism in Valladolid. During a given year Gómez paid out 90,000 maravedis to his sisters who were professed nuns in the city's convents: 40,000 to his sister María at Santa Clara; 40,000 to Ana, also at Las Huelgas; and 10,000 to Juana who had entered San Quirce. Gómez claimed these payments, in addition to the financial support that he offered his daughters, made it impossible to meet Inés' demands. ${ }^{1}$

Gómez' circumstances mirrored the relationship between the citizens of Valladolid and its convents. By 1650 over twenty convents called Valladolid home, in comparison to only thirteen male foundations. Twelve of these female houses had been founded between 1545 and 1650 , a period that saw the creation of only five monasteries. The creation and sustenance of these institutions would not have been possible without the support of the local citizenry. Vallisoletanos were generous in their support. In 1505, for example, a wealthy citizen requested burial in the convent church of Santa Isabel. In return he offered the community a substantial endowment of 47,500 maravedis and an additional 3000 maravedis for work on the church. ${ }^{2}$ The founders of the Dominican convent of Madre de Dios amply endowed the houses with an annual rent of 800 ducados. ${ }^{3}$ In the late sixteenth century Francisco Enriquez de Almansa and his wife, Mariana de Zúñiga y Velasco, donated an annual rent of 200,000 mrs. to the convent of the Descalzas Reales. ${ }^{4}$ In an era of inflation and a growing tax burden, the willingness of these citizens to support female monasticism suggests that they found its presence in their city efficacious and desirable. ${ }^{5}$

As a result, female monasticism in Valladolid flourished in the early-modern era. Yet the picture was not always entirely rosy. Beneath the surface of this mutually beneficial relationship between convents and secular society lay a more complicated social matrix in which professed nuns, despite the constraints of the cloister, remained closely tied to their familial patrimonies. Daughters entered convents with dowries and maintenance allowances, and their families had a responsibility to meet these financial obligations. Nuns, for their part, seemed unwilling simply to assume that their families would honor these contracts. Instead, the protection of these property and inheritance interests required them to remain aware of their families' financial status and economic decisions. Even in the Tridentine world which demanded strict claustration of all solemnly professed religious women, these women monitored the finances of their families and insisted upon the prompt payment of various sums. In fact, this vigilance seems to have been necessary. The records of Valladolid's convents reveal that especially from the mid-sixteenth century forward nuns, their convents initiating 
proceedings on their behalf, entered into oftentimes protracted secular lawsuits with their natal families over disputes involving dowry payments, the receipt of their yearly maintenance allowance, and their rights to familial inheritances subsequent to their profession.

This activity is significant for the social history of early-modern Spain for two reasons. First, in their battles to seek restitution, nuns demonstrated a profound sense of connection to family property. This "connectedness" greatly enhances our scholarly understanding of women and the exercise of property rights in the early-modern era. A growing body of scholarly literature has examined the legal position of secular women vis-à-vis the familial patrimony in medieval and early. modern Europe. ${ }^{6}$ These studies have urged us to look beyond the prescriptive limits of legal codes to see that women, in practice, did sometimes administer considerable property interests as testators, heirs, and patrons. The examples to be outlined here of nuns who continued to identify with and stake claim to their family's property add a new twist to this literature. Nuns maintained a curious self-image by which they remained viscerally tied to their natal families despite the vows that presumably divorced them from these concerns. This study thus reveals that nuns used their religious dowries and maintenance allowances as an opportunity to exercise fiscal influence and autonomy. Second, these conflicts are significant for what they reveal about the clash of both legal and social expectations. Each side believed the law was on their side, but their arguments were also predicated on expectations, perhaps shaped by law but also by larger cultural forces, which defined the "proper" behavior of female religious and the care owed by family members to their own. As such, these disputes illuminate a complicated social world in which the lives and interests of professed religious, despite the physical and spiritual barriers of the cloister, continued to intersect with the calculations and preoccupations of their families.

Any understanding of these conflicts should be grounded in a complete understanding of the dramatic transition signified by a daughter's profession in a convent. By the mid- to late sixteenth century, bowing to the dictates of the Council of Trent, this was an increasingly formalized ceremony. The woman making a profession stood at the door to the monastic cloister and answered a series of questions put to her by the bishop or some other ecclesiastical dignitary. These questions ensured that her profession was true and voluntary and that she was prepared to live by the disciplinary and pious standards of the monastic community. This ceremony also signaled the beginning of her novitiate-a yearlong "trial" period in which she lived among the convent community, observing its rules and strictures. At the end of this year, if it was still her will to enter the monastic life, she made her formal profession and took her solemn vows, thereby becoming a fully recognized member of the community.

This transition involved her welcome into a new community, and as some have argued, a new "home" in the fullest sense of that word. ${ }^{7}$ It was also supposed to mark a break with the woman's natal family and worldly connections. This severing of ties to the secular world was emphatically underscored by the contract that accompanied the ceremony made at the beginning of the woman's novitiate. This contract, which was both financial and religious in its implications, served to set the rules for all subsequent interactions between the woman and her family. 
Not unlike a marriage contract, this document transferred the daughter from her natal home to her new family, in this case, the convent. In theory, this signified that she became "dead to the world" and all things temporal. A significant part of this contract was the renuncia with which a woman renounced all claims to future inheritances or familial property.

Although they were turning their back on the secular world, nuns were entitled to a dowry at the time of their profession according to Spanish inheritance law. This dowry was essentially an advance on the daughter's inheritance from her father (a system of partible inheritance, though subject to numerous manipulations, was in force in Spain) and was composed of her share of his bienes libres (the heritable portion of an estate). Because she was enjoying this inheritance during her father's lifetime and because she was entering a religious house and taking an at least modified vow of poverty, a daughter typically renounced her claims (made a renuncia) to all future inheritances. ${ }^{8}$

Yet the evidence suggests that the renuncia did not mean that daughters definitively severed their ties to familial property. For many nuns, the renuncia was a potentially empowering experience. Many women used the renuncia as a legal opportunity to administer at least portions of what it was they were renouncing. ${ }^{9}$ As they renounced their rights to future inheritances these women designated who could receive them in their stead. Female relatives figured prominently in these designations. Juana de Heraso made her renuncia in 1597 when she entered Santa María de las Huelgas. She renounced any future inheritances to the benefit of her mother. ${ }^{10}$ This renunciation, however, was conditional. In return, she requested that her mother pay her dowry, alimentos, and the costs of her veil (Juana's father was dead). If her mother did not fulfill these obligations then Juana ordered that her renuncia would go to her brothers. Luisa de Collantes made her renunciation in favor of the aunt who paid her dowry and other entrance expenses. " Inés and Manuela Villamicar used their renuncias to provide for their mother since their father was dead. Each woman, upon making her profession (the dates of their profession were separated by five years), left property to their mother, Manuela de Castro. ${ }^{12}$ In 1600 María de Larieta re-made her renuncia. ${ }^{13}$ Originally she had made her renuncia in favor of her brothers and sisters. Yet by 1600 they had all died and therefore María was redirecting her renuncia to the benefit of her aunt.

In the case of Catalina de Luna, the renuncia was a de facto will..$^{14}$ Claiming the right to "dispose of her estate as well as the legítimas from my parents" (her parents were dead and her grandmother appeared with her when she made her profession), she endowed the chapel of the Incarnation at the convent of San Quirce where she was making her profession. Inés Gasca used her renuncia to "will" 600 ducados to her female servant to be put towards the young woman's dowry. 15

The renuncia could be subject to other qualifications. At Adriana Helso's profession she did not renounce all of her legítimas or rights to the future partible inheritance of her parents. ${ }^{16}$ She reserved at least 300 ducados, specifying that her brothers and sisters could not withhold this amount from her. If her legítimas exceeded 300 ducados, the surplus was to go to her convent, Santa Isabel. Similarly, María Turregano reserved 20,000 maravedís of her legítimas for 
herself, specifying that the sum would go to her convent, Santa Catalina, upon her death. Her sense of proprietorship was clear: she referred to this amount as "her estate."17

Other financial considerations, in addition to the dowry, tied daughters to the familial patrimony. Families were usually required to pay a fixed yearly maintenance allowance or alimentos to cover their daughters' incidental expenses beyond those met by the convent. Further, most convents distinguished between the period of a woman's novitiate and her formal profession. Families were supposed to provide in both instances. Thus, when Gregoria de Pereda expressed her intent to enter Santa Isabel her family obligated itself to provide a dowry of 800 ducados when she made her formal profession. During the year of her novitiate it was supposed to give the convent 100 ducados as a maintenance allowance. Finally, the family was to furnish 12,000 maravedis every year after her profession for her food and clothing. ${ }^{18}$

Convents also required other payments. Over time, these became more and more complex. The profession of Vitoria Espinosa y Guevara at San Quirce in 1629 , for example, obligated her family to make the following financial provisions: 1000 ducados for her dowry; 50 ducados of alimentos during the year of her novitiate; 130 ducados for wax and other necessities on the day of her profession; 200 reales for an altar cloth when she took the habit; and 50 ducados yearly for her necessities, clothes and furnishings. ${ }^{19}$ At María Antonia Gardoyque's profession in 1671 she and her family pledged to pay an entrance fee (literally propinas, a tip or "extra") of 100 ducados, a profession fee of 100 ducados, and 50 ducados as a type of trousseau on the day she took the habit. ${ }^{20}$ All of these payments were in addition to her dowry and alimentos. Upon agreeing to pay the dowries required by Santa María de las Huelgas, the father of Gregoria de Vera and Juana de Vera y Herrera also pledged to provide the "customary fees" (propinas acostumbradas) of 220 ducados that went towards wax, food, and collations, on the day they took the veil. ${ }^{21}$ Because these payments were made as supplements or incrementally, they necessarily required the female relative to maintain a connection to family property. If they were not paid promptly, the nun and the convent had a financial stake in securing the family's compliance.

It was not only dowries, alimentos, and other financial sums required by the convent that allowed professed daughters to remain connected to their families' property. Although Spanish law honored the practice of partible inheritance, siblings might also be in line to receive other sums. Parents, in fact, enjoyed a certain flexibility in acting as testators. A father or mother could set aside up to one-fifth (an amount known as the quinto) of his or her estate for free bequests. If the total of these free bequests totaled less than one-fifth, the remaining sum, the remanente del quinto, could be designated as a special bequest or mejora. There was also another option. Each parent could alienate an amount known as the tercio which was one-third of his or her estate as a bequest to an heir of his or her choosing. ${ }^{22}$ What remained after any of these extraordinary bequests, however, had to be distributed among all the necessary heirs, each of whom was entitled to his/her partible share or legítimas. ${ }^{23}$

Particularly by the sixteenth century, however, an additional tension had been introduced into the system of partible inheritance. This was the mayorazgo or entailed estate. ${ }^{24}$ It was typically passed on to future generations according to 
a system of primogeniture and could not be alienated. ${ }^{25}$ By the early-modern period, the mayorazgo had become an increasingly popular means for the Spanish nobility and social aspirants to amass large familial patrimonies. At the beginning of the sixteenth century, in an attempt to curry the support of the nobility, King Ferdinand had greatly liberalized the laws governing the creation of mayorazgos. Thus, noble and even non-noble families incorporated great amounts of their patrimony into these entailed estates. Significantly, mayorazgos also privileged the eldest male heir, thus creating a system of primogeniture that existed in tension with the prevailing standards of partible inheritance. Finally, mayorazgos placed increasing emphasis on the agnatic kin group and signaled a shift away from a more bilateral system that traced lineage and prestige through both mother and father. Mayorazgos, then, were designed to consolidate a family's prestige, but that prestige was defined in male terms and was intended for the benefit of male family members. This shift to primogeniture prompted numerous challenges. The laws governing these estates were not always clear, and confusion reigned as to what portion of a family's patrimony could be legally transferred to the mayorazgo. Numerous disputes erupted as a result of this ambiguous situation, particularly among those who felt that they had been robbed of their fair share because too much property had been incorporated into the mayorazgo. ${ }^{26}$

Thus, many considerations ensured that the moment of religious profession was not always a straightforward legal and financial transfer of a female relative from her natal family to her new home in the convent. Profession and a declaration of renunciation did not mean that female relatives had severed all ties to the secular world. The following discussion of several specific lawsuits will continue to reveal the ways in which nuns and their families clashed over the relationship of these now-religiously professed women to their familial patrimonies. These disputes reveal the employment of a range of strategies, some more honorable than others. Both nuns and their families seemed reasonably well-versed in the legal practicalities that governed these predicaments and both sides worked within a law that was flexible and subject to interpretation. And when legal resort failed there was always deceit.

In these disputes the role played by the convents as corporate actors in the legal system becomes clear, thereby underscoring the individual nun's incorporation into the life of a new "family." To begin with, convents regarded dowries, alimentos, and other sums of money that accompanied a woman at her profession as corporate property and duly recorded them in their account books as part of the community's collective assets. ${ }^{27}$ Convents drew considerable financial security from the profession of these women. Valladolid's daughters entered the convents in large numbers in the sixteenth century. At mid-century the number of nuns in Valladolid was estimated at approximately 595 out of a population of approximately 40,000 (compared to 615 monks) ${ }^{28}$ Most of these communities commanded sizable dowries. By the early seventeenth century most convents in the city were requiring a dowry of 1000 ducados. ${ }^{29}$

Most strikingly, it was the convents that filed these lawsuits. Though they would be represented in the courts by their secular appointees, convents nonetheless initiated the legal proceedings that exposed these conflicts between sacred communities and the secular world. In so doing, the convents asserted an identity by which they conceived of themselves as institutions with a legitimate presence 
in the temporal world. ${ }^{30}$ The foundation of many of these convents had been attended by the bestowing of privileges, endowments, and property designed to provide them with financial support. ${ }^{31}$ From this starting point, these foundations had augmented their financial resources through careful management and the cultivation of further patronage relationships. In so doing, they had created for themselves an undeniably secular presence. While their existence and support rested on their spiritual responsibilities, they nonetheless possessed a concurrent mission by which they defined themselves as institutions that had to protect their finances in order to continue to prosper. The families with which they did battle in the early-modern period adopted a defensive stance of protecting perceived threats to their social status. Yet convents, by defending their fiscal interests in court, were engaged in an argument of continuity, whereby they sought to preserve their secular identity over the course of the early-modern period.

It is critical to note that the convents' partners in these litigious endeavors were the women in their care. The individual nuns whose cases the convents represented were not passive actors. It was their intimate knowledge of the family's assets and property that would have brought disputes over claims to the family patrimony to the attention of the convent. Yet they could not have pursued these claims without the convents' willingness to speak on their behalf.

One of the most common types of disputes involved payments that were expected after a daughter's initial profession. The payment of alimentos was supposed to be made on a yearly basis. Additionally, dowries were rarely paid in one lump sum. In this era of limited liquid capital a dowry might be paid off gradually through the mechanism of an annuity contract. ${ }^{32}$ Thus, the annual payment toward the dowry could become an additional burden above and beyond the alimentos. In 1662 the convent of Santa Catalina, on behalf of Bernarda de Mercado, entered into a lawsuit with her father's estate, claiming that he had not made sufficient payment on her alimentos. ${ }^{33}$ Santa María de las Huelgas initiated proceedings in 1602 for Rafaela and Juana de Heraso y Herrera who believed they had been deprived of the full sum of their dowries and alimentos. ${ }^{34}$ Their father had died, so it filed suit against his estate to seek compensation. Ultimately, the community was awarded an annuity contract to cover the amount.

Frequently, these conflicts erupted upon the death of a nun's parents. A brother or male relative, recognized as the executor and chief inheritor of the parents' estate, would be accused of withholding payment owed on the dowry or alimentos. These were precisely the circumstances in which Gómez Manrique Mendoza, whose story began this article, found himself. Despite not having been a party to his sister's profession contract, Gómez faced a legal mandate to provide for her.

In 1634 Ana Manrique, a nun at Santa María de las Huelgas, sought to take her brother Antonio Osorio Manrique to court. ${ }^{35}$ At stake were payments owed on her alimentos; she was entitled to 30,000 maravedís each year. As the eldest son, Antonio had inherited the family's mayorazgo or entailed estate and with it the responsibility to honor his family's previous contracts including the one that required him to provide for his sister's maintenance allowance. ${ }^{36}$ Similarly, Santa Catalina took the brothers of Luisa and Maria de Tovar to court in $1596 .{ }^{37}$ Again, the contested issue involved dowry payments that had been negotiated when the two sisters entered the community. As inheritor of two entailed estates 
created by their father, the eldest surviving brother (the first-born son, Diego, had died), Mateo, was obligated to honor his father's debt to the convent.

The arguments offered by those who failed to make these payments reveal a variety of strategies. As already indicated, Gómez Manrique Mendoza cited his compromised financial circumstances. He was already shouldering an enormous burden in meeting the financial needs of his female relatives. Additionally, he found his sister's use of this money unreasonable because she claimed to need it to treat her many illnesses and to pay her servant. Ironically, Inés had already been involved in an earlier dispute with her father over the very same issues. Almost thirty years prior to the lawsuit she filed against her brother, Inés laid claim to money from her deceased mother's estate. ${ }^{38}$ She claimed to need this portion to pay for her dowry, habit, veil, and other expenses associated with her profession at the convent. Her father contested her demand, saying that the convent had already collected substantial amounts from the family. The convent countered that those sums had been for the year of her novitiate, but that her formal profession involved a new set of expenses.

Echoing these sentiments, the father of Isabel de Vega, Gerónimo de Vega, made the cornerstone of his argument the unreasonable financial demands of convents in general and the convent of his daughter's profession, Santa Catalina, in particular. ${ }^{39}$ Asserting that convents had become prohibitively expensive and thus only for the daughters of rich men, Gerónimo argued that Santa Catalina's rents should have been sufficient to cover her maintenance; why, then, should he be obligated to pay her alimentos? As an additional bolster to his argument, Gerónimo displayed knowledge of the Tridentine Church's demand that all professions be voluntarily made and suggested that his daughter had not entered the convent freely. If this were the case, any contracts made at that time were not valid. Even if it was her true will to enter, Gerónimo argued, he still found the convent's financial demands unreasonable and refused to pay them. The courts did not agree with him and he ended up owing 700 ducados.

Ana Manrique's brother, Antonio, also launched several counter arguments in the face of his sister's demands. ${ }^{40}$ One of Antonio's arguments was purely practical and circumstantial. He was about to get married and his impending nuptials involved certain costs that made it impossible for him to meet his sister's expenses. Further, he believed that his sister's claims of illness, which she argued made the payment of alimentos that much more urgent, were groundless.

Antonio also raised an issue centered on the legalities of the mayorazgo. The payments that Ana was demanding of her brother were supposed to come from the mayorazgo that her father had created, yet Antonio questioned the ability of religious women to administer rents or property tied to a mayorazgo. His side, in fact, asserted that religious women were "incapable" (incapaces) of inheriting any portion of the mayorazgo. This assertion brought into dramatic relief how the institution of the mayorazgo could complicate issues of inheritance by raising issues of gender and religion. Technically, the mayorazgo, operating according to a system of primogeniture, was off-limits to female heirs. Yet in practice, daughters were not always entirely excluded from the inheritance of mayorazgos. There is evidence to suggest that parents created mayorazgos for their daughters, though frequently with the expectation that these daughters 
would marry and thus the property would at least be jointly administered by the husband and wife. ${ }^{41}$ In practice, these estates were only rarely intended to become the heritable property of daughters or female relatives. If a woman inherited one it was customary for it to pass quickly to her nearest male relative upon her death. ${ }^{42}$ The only official prohibition that excluded a son or daughter from inheriting a mayorazgo was making a religious profession. ${ }^{43}$ It was probably this prohibition that prompted Antonio to designate his sister and her convent as "incapable" of administering the mayorazgo.

The court, however, found in favor of Ana and ordered Antonio to pay 2100 reales every year to meet his sister's needs. As an indication of the complexity of Castilian inheritance law, the court was able to offer a powerful counterargument. Probably in recognition of the legal right, explicated in the Leyes de Toro (a legal code of 1505 that dealt primarily with issues of property and inheritance), that provided that a woman's dowry could be paid, if necessary, from the rents and appraisal of the property contained in the mayorazgo, the court discredited Antonio's claims. ${ }^{44}$ The distinction here was between the actual administration of the entailed estate-which would have been legally unacceptable-and the right to payment drawn from property encumbered in the mayorazgo.

Convents seem rarely to have been daunted by extenuating circumstances, even if these drew them into conflict with their religious contemporaries. In 1653 the convent of Santa Catalina filed a lawsuit on behalf of three of its nuns: Mariana de Córdoba and Francisca and Isabel de Silva. The three all claimed to be the heirs of their brother, Fernando ${ }^{45}$ The suit challenged the chaplaincy that their brother had founded at a convent in Madrid. Santa Catalina argued that it was still owed for the dowries and alimentos of the three sisters and the interest that these sums would have been accruing. Ultimately, the convent won and was awarded a sum of 37,000 reales.

Numerous other lawsuits centered on the issue of inheritances subsequent to a woman's profession as a nun. For many nuns their status as a professed religious did not necessarily obviate access to various parts of familial patrimony. The bequesting strategies of individual family members suggest that they, too, believed that the renuncia did not necessarily dictate a nun's separation from future inheritances. In 1601, for example, Savina de Lintornes made her will. ${ }^{46}$ In it she made two extraordinary bequests (the mejora of the tercio and the remanente of the quinto) to her daughter, Angela, a professed nun at Santa Catalina. In return, Angela was instructed to help her brother, a Benedictine monk, and to ensure that various masses were said on Savina's behalf. The text of Savina's will indicated that Angela had made all the necessary renunciations when she professed in 1586 . Yet clearly her mother did not see the renuncia as an obstacle to Angela's future inheritance of these extraordinary bequests. It is also worth noting that Savina anticipated possible disputes between her children over her estate and for this reason she urged Angela to assist her brother whenever necessary. She was adamant that her offspring not file lawsuits against each other.

The exhortations of mothers like Savina aside, however, conflict frequently erupted over inheritance rights. The archival evidence of such conflicts is often only fragmentary, but nonetheless revealing. In 1556 the Royal Council ordered the partition of the estate of Pedro Arias. ${ }^{47}$ This was done to the benefit of 
his daughter, Isabel, a nun at San Quirce, who received half of the partitioned amount: 80,000 maravedís. Although the surviving records provide little additional evidence, what is clear is that Isabel, despite being a professed nun, had a stake in her father's estate. Her lawsuit probably began like the one filed by Santa Catalina on behalf of Marina Sarmiento, Bernardina Sarmiento, and María de Rojas. In 1594 it argued that the women were the rightful inheritors of a portion of their father's estate. ${ }^{48}$

Beleaguered finances were frequently at the root of these disputes, with various parties vying for what they believed was rightfully theirs. A protracted series of lawsuits involving María Abreo, the widow of Juan de Turregano, an official for the Council of the Indies, illustrates this well. María was entangled in a long dispute with her daughter, María de Turregano, a professed nun at Santa Catalina. ${ }^{49}$ María Abreo's greatest dilemma throughout her lifetime seems to have been her own and her husband's indebtedness. In 1540, their son-in-law, Juan de Salablanca, took his father-in-law to court over the proper payment of the dowry that had been negotiated when he married another of Juan de Turregano's daughters, Isabel. ${ }^{50}$ Juan de Salablanca argued that Juan de Turregano still owed him 500 ducados; the court agreed and ordered Juan de Turregano to pay. In 1560 María de Abreo was cited for owing money to Francisco de Madrid, a pharmacist. ${ }^{51}$

By 1571 Santa Catalina had entered into the fray, claiming that María Abreo owed them money that was rightfully María de Turregano's as one of her father's heirs. ${ }^{52}$ Before the lawsuit could be resolved, Maria Abreo died. This obliged the Council of the Indies, Juan de Turregano's former employer, to make the necessary payments. The dispute was evidently complicated by the fact that there were sums of money owed to Juan de Turregano's estate that had not been paid. ${ }^{53}$ By 1585 Philip Il was involved in the conflict. He ordered the collection of monies owed to Juan de Turregano's estate so that these could, in turn, be used to pay the debt to Santa Catalina. ${ }^{54}$ Unfortunately for Santa Catalina, María de Turregano apparently inherited her family's financial woes. In 1570 the convent ordered an accounting of María's finances, seeking the proper payment of monies owed to it. ${ }^{55}$ As an epilogue to the story of Santa Catalina's interaction with this family, María Abreo's will testifies to the fact that she may have felt some remorse for the complications involving her daughter's inheritance. She specified that all of her goods be given to Santa Catalina. ${ }^{56}$

Sometimes inheritance disputes began with professed nuns claiming a portion of a brother's estate. In 1575, for example, the convent of Santa María de las Huelgas, acting in the interest of one of its professed nuns, Ana de Mendoza Quijada, filed a lawsuit against her sister-in-law, Madalena de Ulloa. ${ }^{57}$ Madalena had been married to Ana's deceased brother, Luis, and Ana claimed that she had a right to a portion of his estate. Madalena, as might be expected, argued that Ana had made a renuncia when she professed and that it obviated any future claims to the family patrimony; in addition, Madalena claimed the contract made at Ana's profession made ample provisions for her financial well-being. Madalena further argued that, as a religious woman, Ana ought to be especially concerned about setting a good example by honoring this original contract.

The convent countered with two inconsistent arguments. To begin with, it contended that Ana had at her profession renounced her rights to any legitimas 
from her parents but not from her brothers. Thus, by this argument, Madalena, as the chief inheritor and administrator of Luis' estate, was obligated to honor Ana's claim. Further (and perhaps just to be safe), the convent said that Ana's renuncias of her parental legítimas had not been properly made and were thus invalid (in this, of course, the convent also implicated itself for failing to secure the proper contract).

Santa Catalina filed a similar claim against the estate of Diego Sarmiento in $1614 .{ }^{58}$ One of its nuns, Mariana, claimed that she had a right to a portion of her brother, Diego's, property. The complicating factor in this case was that some of Diego's property was tied to his inheritance from his aunt, Teresa de Figueroa. The convent thus entered into an additional case with the inheritors of Teresa de Figueroa's estate, seeking the eventual restitution of amounts that her nieces and nephews claimed. ${ }^{59}$ Their claims, however, were slowed by the excessive complications involved in Teresa de Figueroa's estate. Teresa's brotherin-law was alleged to have withheld from her various payments, which her heirs believed constituted their rightful portions of her estate.

When legal arguments and mitigating factors could not be rallied, it appears that deceit was not beyond the scope of avaricious relatives. Convents were sometimes the victims of trickery. In 1515 an attempt by several individuals to circumvent the inheritance of the daughters of Francisco de Cueto and Juana de Ochoa, professed nuns at Santa Catalina, was uncovered. In 1517 the deceivers were excommunicated for their treachery. ${ }^{60}$

In 1591 two nuns of Santa María de las Huelgas, Isabel and Francisca de la Cerda (Isabel was the abbess of the convent), urged the initiation of a suit against their brother's widow, Catalina Manrique. The sisters of Luis de la Cerda claimed to be the rightful inheritors of his estate. The will presented by his widow and a clerk, Juan de Estrada, however, indicated that Luis had willed his estate to the chapel of San Juan Bautista in the parish church of San Salvador. The chapel had been founded by don Luis' great-great-grandparents, Goncalo González and Marina de Estrada.

The case was originally heard in 1591 and the court found in favor of Catalina and Estrada. Two years later the case was appealed to the Real Chancillería which revoked the earlier decision and ordered the defendants to turn over don Luis' estate to the nuns within nine days. The crux of the Real Chancillería's decision rested on the fact that Catalina and Estrada had presented a false will that did not represent Luis' true intentions. The will they presented was apparently only a draft and had not been officially signed and sealed. Another heavily annotated copy of the draft was found among Luis' papers. Portions had been erased and notes had been made in the margins which indicated that he did not intend for his estate to further the devotional cult at the chapel in San Salvador. ${ }^{61}$

A more thoroughgoing examination of what each side had at stake in these disputes reveals that the early-modern period witnessed significant fluctuations in the relationship between Valladolid's convents and the families of the female relatives professed there. Valladolid's families, for a variety of reasons, increasingly wrestled with the conflicting pulls of preserving the familial patrimony and showing their support for female monasticism. The convents fought for financial stability and the opportunity to assert themselves as institutions with legitimate interests in the secular courts of the day. These were mutually incompatible goals 
whose clash resulted in the types of disputes outlined above. Further, both sides sought these goals at great expense. Lawsuits were costly ventures. ${ }^{62}$

For Valladolid's families the expense was justified in part because their estates made powerful statements about their economic and social worth. Wealthmeasured both as land and the ability to spend-was a chief determinant in assessing a family's place in the social pecking order. For older noble and patrician families, and the families of socially ascendant groups alike, the sixteenth and seventeenth centuries also witnessed the full flowering of trends begun in the later Middle Ages that put increasing emphasis on the intangible concepts of family name and lineage. Property and financial prosperity were powerful testimonies to the strength of each of these categories and a buttress to weak claims to either.

Historians of Castilian noble families in the Middle Ages have found from the thirteenth century onward the development of patterns signifying a growing interest in the documentation and outward, physical demonstrations of lineage among kinship groups tracing their origin to an ancestral past. ${ }^{63}$ The use of familial surnames, heraldic emblems, family pantheons, family chronicles, and genealogical compilations all speak to a growing fascination with creating evidence of family name and lineage-evidence that frequently manifested itself visibly in public testimonies, such as displaying a coat of arms on one's palace or burial markers in a church that indicated that members of a family were buried together.

As would be expected, an additional and critical manifestation of a family's lineage was its property: "a family's prestige and influence were regarded as indissolubly tied to the availability of the greatest number of rents and patrimonies." 64 Further, this property was regarded as a collective representation of the family name and not simply the individual property of the male family member entrusted with administering it at a given point in time. ${ }^{65}$ From this it naturally followed that a fragmented patrimony was symptomatic of a fragmented family that lacked a strong sense of identity ${ }^{66}$ Fathers despaired of seeing these properties diminished or carved into smaller holdings, asserting that this would result in the dilution of the family's sense of worthy ancestry. ${ }^{67}$ It was this mentality that gave birth to the significance of the mayorazgo. Over time, and with the liberalizing of laws governing their creation, the mayorazgos became a powerful statement of a family's good name and lineage.

All of these strategies for asserting lineage were gradually adopted by other groups seeking a higher social status. The urban patriciate and emerging social groups like wealthy merchants, financiers, and letrados (university-educated clerks and secretaries who served the royal and ecclesiastical bureaucracies) adopted similar means to stake their place in the social landscape of early-modern Castile. These groups were prospering financially and enhancing the Spanish economy. In turn, they sought to translate their financial strength into social and political strength and the acquisition of noble privileges like exemption from taxation.

Families knew that their successful integration into the noble ranks of society rested on their lineage being recognized as worthy. ${ }^{68}$ The measurement of such 
worth took a variety of forms. One means of accomplishing this was to elevate themselves to noble status. There were, for example, various public acts and proceedings that could achieve this. There was the legal mechanism of the pleito de hidalguía, a petition by which a family claimed noble status. Though these legal proceedings were subject to widespread corruption, they remained an attempt to produce tangible evidence of nobility. Witnesses, patents, and other devices were offered as "proof" of nobility.

Short of such legal recognition, there were other means of asserting a family's good name. Registers that listed recognized members of the nobility or ruling elite also announced publicly a family's status. ${ }^{69}$ Intermarriage with the aristocracy was another popular tool throughout Europe in the early-modern period. Even an alignment with pious movements and reformed religiosity could be a socially empowering experience that signified a family's place in the community. ${ }^{70}$

In what became a vicious circle, the social pretensions of letrados and others anxious to assert their families' good names and contest the existing social boundaries, encouraged the nobility and the established urban patriciate to rush to protect the exclusivity of their wealth and lineage. ${ }^{71}$ Each group sought selfdefinition, at least in part, by creating a sense of lineage that would be apparent not only to them, but to their contemporaries. What had begun as a trend among the nobility in the late Middle Ages, became the preoccupation of the socially and economically powerful in early-modern Spain. The liberalization of laws governing the mayorazgo, for example, allowed non-noble families to found them, thereby protecting their claim to respectable social standing.

Into this complicated social world stepped daughters making religious professions. As a condition of such professions, convents required dowries and maintenance allowances, thus requiring families to alienate permanently portions of the familial patrimony. Knowing this, families expressed their wariness of tying too much property to their daughters when these women expressed their intent to enter a convent or set conditions for the payment of their debts. In 1597, for example, Pedro Osorio pledged to give the convent of Santa María de las Huelgas 1000 ducados for his daughter's dowry. ${ }^{72}$ Pedro's intentions were good. The money was earmarked for repairs on the convent church. Yet he specified that if his daughter failed to profess (presumably after her novitiate), the money had to be returned to him.

The seriousness of the threat felt by family members upon seeing a portion of the familial patrimony destined for a religious foundation emerges from the story of the foundation of the convent of Santa Catalina in Valladolid. In the late-fifteenth century María Manrique and her daughter, Elvira, discussed their intentions to found a convent. Her sons, hearing of their mother's plan and angered by her decision to use a portion of the family fortune in this venture, decided to kill her before she could realize her goal. Made aware of this plot, María fled her palace for the safety of a convent of Dominicans in a nearby town. She arrived at the doors of the convent while the abbess was praying in front of the church's crucifix. The figure of Christ on the cross spoke to the abbess and ordered her to open the door to the woman fleeing from her sons. ${ }^{73}$ Perhaps as testimony to the bravery and tenacity of Maria, the mouth of the figure of Christ on the crucifix was said to remain open from that day forward.

Clearly, a decision that would permanently alienate property in favor of a 
daughter making a religious profession had to be carefully monitored. It was in an instance such as this that female monasticism differed sharply from its male counterpart. Male monasteries did not require dowries of their professed members and represented less of a threat to the family patrimony. A daughter's profession, however, transferred a portion of the family's estate and hence part of the sense of lineage to a religious institution. Additional threats were posed by the autonomy with which these women administered these properties through the act of making a renuncia. As demonstrated earlier, professed nuns were able to use their renuncias to assign property to relatives and causes of their own choosing, thereby further partitioning a family's property.

Families might have been able to persuade themselves that they were facilitating their own salvation and forging close ties to the divine when their daughters entered convents and alienated family property on behalf of the church. That their daughters were also using their professions as an opportunity to alienate future inheritances, however, struck a double blow. Ironically, religious profession and the renuncia could create an opportunity for women to administer property autonomously. Under these circumstances, the vigorous response of families to the lawsuits of their professed female relatives becomes more clear. In this period of heightened concerns with lineage, the chance that portions of the family estate might devolve to either a convent or female relatives constituted a significant threat to the self-definition of these families.

Thus, these families had to strike a careful balancing act. Women did, in fact, continue to make religious professions and families, for their part, continued to support this path as an acceptable choice for their daughters. Religious dowries, though not inconsequential, were typically smaller than secular dowries. There were various efficacious reasons for supporting female monasticism, including salvation, proximity to the divine through the intermediary of a family member, and the bolstering of the virtue of female chastity. At the same time, however, families had to balance these considerations against the mounting social significance of their estates. While they might not be able to abandon the prospect of letting their daughters profess, they could at least challenge these same daughters when later confronted with their legal claims.

The convents wrestled with their own dilemmas when they decided to initiate legal proceedings against the families of their nuns. As indicated earlier, their decision to launch legal proceedings was predicated on their self-conception as institutions with legitimate fiscal and temporal interests, not unlike the ones possessed by their temporal contemporaries. It was in this context that dowries and alimentos took on a significance beyond their monetary value when their payment was witheld. If the convents sacrificed their interest in these sums, they sacrificed a part of their identity. This in turn explains why the convents argued their cases in the secular, and not ecclesiastic, courts of the day. ${ }^{74}$ The ecclesiastic courts, given the scope of their jurisdiction, could have heard at least some of these cases. ${ }^{75}$ Yet it was possible to argue that these cases belonged in the secular courts. Widows seeking the restitution of their dowries after their husbands died, for example, frequently litigated in the secular courts. ${ }^{76}$ Nuns in some ways were not so different from these widows. They, too, as we have already seen, regarded themselves as autonomous, secular actors with the power to administer property. Convents sought justice in a court consistent with their own self-image, thereby 
reinforcing that same image. Though spiritual institutions they had temporal interests that required temporal protection.

Yet the assertion of this identity by convents and their nuns entailed risks. Most significantly, filing a lawsuit put their relationships with their patrons at risk. As demonstrated at the beginning of this article, the support of vallisoletanos for convents had allowed female monasticism to flourish in the earlymodern period. Beyond their creation, convents were dependent on the continued support of their patrons and the expectation that the generosity of one patron would attract the attention of future philanthropists. The oldest convents in the city (founded before 1500), for example, having established their reputations as revered institutions, continued to attract patronage throughout the early-modern period. The king's chaplain (1609), Luisa de Zarraga (1613), and Jerónima Ponzano (1593) all chose burial in chapels at the convent of Santa María de las Huelgas (founded in 1282). ${ }^{77}$ In 1598 Juan Acacio Soriano, a lawyer in the royal appellate court in Valladolid, built a chapel in the convent church of Santa Catalina (founded in the late-fifteenth century). ${ }^{78} \mathrm{He}$ also willed the community tapestries and relics. María Montora donated two plots of land to Santa Clara in $1596 .{ }^{79}$ In 1598 Santa Isabel enjoyed the beneficence of Ana Paredes Aldrete who left the convent a rent worth 1000 maravedís a year. ${ }^{80}$

Regardless of when they had been founded, the convents also depended on patronage and other relationships built on family ties. Wills from the period suggest that professed female relatives were often on the minds of their families. In 1522 María de la Torre made her will and left her sisters, nuns at Santa Catalina, an annuity contract. ${ }^{81}$ She felt compelled to do this, she said, because she held the convent in high esteem. Ana Paredes Aldrete left her sister Isabel, a nun at Santa Isabel, a retablo, 20 ducados, and the revenue from an annuity contract. ${ }^{82}$ Her daughter, Andrea, also a nun at Santa Isabel (perhaps following the example of her aunt) received the revenues from another annuity contract.

Undoubtedly, the presence of a female relative in a convent was a powerful force in attracting subsequent professions. This was another instance, in fact, in which it became clear that female relatives cloistered in convents were not dead to their families and continued to exert a powerful influence if simply through their pious examples. Both Luisa Salcedo and Manuela de Villamicar followed their sisters into the convent of Santa Isabel. ${ }^{83}$ Isabel and María Espinosa professed at Santa Isabel where their father's aunt was the abbess. ${ }^{84}$ Sometimes the presence of a sister could be especially instrumental. When her sister Mariana wanted to profess at Santa María de las Huelgas where she was already a nun, but lacked the necessary sum for her dowry, Inés de Velasco pledged her own estate to cover her sister's expenses. ${ }^{85}$

The disputes discussed in the course of this article prompt two significant observations. The first observation is that families seemed increasingly reluctant to alienate the familial patrimony to the benefit of their female relatives who had made religious professions. Whether out of simple greed, financial overextension, or interpretation of the law, they put up these defenses at the possible risk of tainting their relations with revered religious foundations whose existence they found socially and spiritually valuable. In late-medieval and early sixteenth century Spain, convents were extraordinarily popular outlets for local charity and generosity. For what they offered their patrons in terms of spiritual 
and social reassurance and clout, convents were an indispensable part of the religious landscape. The continued willingness of vallisoletanos to found these communities, provide them with financial security, and encourage their daughters to enter them attests to these enduring cultural values. At the same time, however, Valladolid's citizens felt the conflicting pull of other social concerns. In an era of profound preoccupation with lineage and the significance of property in embodying this sense of lineage, these same citizens came to be threatened by the alienation of property into the hands of their female relatives who were professed nuns. Families whose daughters entered convents often found themselves on the horns of a dilemma. These institutions were typically central to their own spiritual well-being and social self-definition. Many of the same socioeconomic circumstances that encouraged their patronage of convents, however, also encouraged the preservation in both real and symbolic terms of the familial patrimonies.

The second observation is to highlight the tenacity with which convents pursued the payment of dowries, maintenance allowances, and inheritances on behalf of their nuns when they filed lawsuits in the secular courts. At the risk of alienating their would-be patrons, convents asserted their right to behave as secular actors, protecting financial resources and managing their own patrimonies. Their ability to act in this manner was predicated on individual nuns presenting themselves, despite legal parameters, the boundaries of the cloister, and their status as professed religious, as secular actors with valid property rights. Clearly, convents and their nuns conceived of themselves as spiritual intermediaries with secular interests. Nuns remained connected to familial property through a variety of mechanisms and did not hesitate to initiate proceedings when these claims were in jeopardy. Convents rallied around these women out of corporate financial interest and as a means of maintaining this secular identity. Thus, the litigious behavior of convents, acting on behalf of their nuns, provides historians with a significant example of the exercise of fiscal influence by women and their institutions.

The lawsuits analyzed here represent the clash of various and conflicting understandings of the place and efficacy of convents in early-modern Spain. Convents saw their value defined in spiritual terms and their place as one measured by religious and temporal concerns. Families became less comfortable with the secular component of this definition as it threatened their own social selfdefinition. In these wranglings over dowries and inheritance, nuns and their families became part of a larger dialogue about the place of convents in earlymodern Spanish society-a place that was still subject to considerable debate.

Department of History

Cleveland, $\mathrm{OH} 44115$

\section{ENDNOTES}

The initial research that forms the base of this article was funded by the History Department, Women's Studies Program, and University Graduate School at Indiana University. Additional research was made possible by generous funding from a National Endowment for the Humanities Summer Stipend, a subvention grant from the Program for Cultural 
Cooperation between United States' Universities and Spain's Ministry of Culture, and a Bernadotte E. Schmitt Grant from the American Historical Association. I would also like to thank David C. Spaeder and the readers for the Joumal of Social History for their helpful comments on earlier drafts.

1. Gómez' financial woes would continue; the court found in lnés' favor and ordered Gómez to pay 100 ducados each year for lnés' allowance. Archivo Histórico Nacional (hereafter AHN), Clero, Libro 17018.

\section{AHN, Clero, Libro 17516.}

3. Matías Sangrador y Vitores, Historia de la muy noble y muy leal ciudad de Valladolid, vol. 2 (Valladolid, 1851-1854), 326-7.

4. Juan José Martín González and Francisco Javier de la Plaza Santiago, Monumentos Religiosos de la Ciudad de Valladolid, vol. 14, part 2 of Catálogo Monumental de la Provincia de Valladolid (Valladolid, 1987), 92-108; Sangrador y Vitores, Historia, vol. 2, 327-8.

5. It should be noted that this is in marked contrast to the complaints of some earlymodern Spanish cities during this period when faced with the prospect of supporting new monastic foundations for women. See, for example, the resistance of Avila when St. Teresa sought to make her first discalced Carmelite foundation there. Jesús Molinero, "Actas municipales de Avila sobre la fundación del monasterio de San José por Santa Teresa," Boletin de la Real Academia de Historia 66 (1915): 155-85; Jodi Bilinkoff, The Avila of Saint Teresa: Religious Reform in a Sixteenth-Century City (Ithaca, 1989), 137-51.

6. Some of the most extensive literature on this subject comes from studies of the dowry and inheritance in Italy. See, for example, Thomas Kuehn, Law, Family, and Women: Toward a Legal Anthropology of Renaissance Italy (Chicago, 1991); Stanley Chojnacki, "Patrician Women in Early Renaissance Venice," Studies in the Renaissance 21 (1974): 176-203; Idem., "Dowries and Kinsmen in Early Renaissance Venice," Journal of Interdisciplinary History 4 (1975): 571-600; further, recent literature on women as patrons is also quite revealing of the power of women to administer property. See, for example, the essays in Cynthia Lawrence, ed., Women and Art in Early Modern Europe: Patrons, Collectors, and Connoisseurs (University Park, PA, 1997) and June Hall McCash, ed., The Cultural Patronage of Medieval Women (Athens, GA, 1996).

7. See, for example, P. Renée Baernstein, "In Widow's Habit: Women between Convent and Family in Sixteenth-Century Milan," Sixteenth Century Journal 25/4 (1994): 797-807. This is also a useful article for another example of how the lives of women in convents continued to intersect with their secular families.

8. For comments on this practice in early-modern Italian convents see Baernstein, "Widow's Habit," 793-4. It should also be noted that the renuncia seems to have achieved greater significance in the period after the Council of Trent. The statements of profession that I have seen from the period before 1550 frequently observe very few formalities, including making an official renuncia. Significantly, most of the lawsuits involving disputes over the terms of individual renuncias also date from this Tridentine period.

9. This may have been a legal means around the prohibition against professed religious making wills. Samuel Parsons Scott, trans., Las Siete Partidas (Chicago, 1931).

10. AHN, Clero, leg. 7804.

11. AHN, Clero, leg. 7910.

12. Ibid.

13. Ibid. 
14. AHN, Clero, leg. 7790.

15. AHN, Clero, Libro 17256.

16. AHN, Clero, leg. 7910.

17. AHN, Clero, leg, 7847.

18. AHN, Clero, leg. 7910.

19. AHN, Clero, leg. 7794.

20. AHN, Clero, leg. 7910.

21. AHN, Clero, leg. 7803.

22. More accurately the tercio was one-third of one-half since each parent took his or her tercio from one-half of their common property.

23. This understanding of Spanish inheritance law is drawn from an article that Muriel Nazzari brought to my artention: Eugene H. Korth and Della M. Flusche, "Dowry and Inheritance in Colonial Spanish America: Peninsular Law and Chilean Practice," The Americas 43 (April 1987): 398. See also David S. Reher, Perspectives on the Family in Spain, Past and Present (Oxford, 1997), 50-3. For the tradition of partible inheritance see Richard L. Kagan, Lawsuits and Litigants in Castile, 1500-1700 (Chapel Hill, 1981), 131; and Heath Dillard, Daughters of the Reconquest: Women in Castilian Toun Society, 11001300 (Cambridge, 1984), 26. Further, I have seen the legitimas defined as a portion of the parents' joint estate or as a portion of the individual estate of the mother or father. In 1622 , for example, two nuns at Nuestra Señora de Belén demanded the payment of their maintenance allowance which was drawn from their maternal legítimas: AHN, Clero, leg. 7761 .

24. A helpful explanation of the evolution and legalities of the mayorazgo is provided by Bartolomé Clavero, Mayorazgo: propiedad feudal en Castilla, 1369-1836 (Madrid, 1989).

25. Although there is evidence to suggest that mayorazgos were often alienated; see Isabel Beceiro Pita and Ricardo Córdoba de la Llave, Parentesco, poder, y mentalidad: la nobleza castellana, siglos XII-XV (Madrid, 1990), 237.

26. See Kagan, Lawsuits, 130-1; and Helen Nader, "Noble Income in Sixteenth-Century Castile, the Case of the Marquises of Mondejar, 1480-1580," Economic History Review 30 (August 1977): 414 .

27. See, for example, the entries in AHN, Clero, Libros 17501, 16986, and 16961. What remains unclear is the expenditure of these sums and how much individual control each nun had over those amounts destined for her maintenance.

28. Bartolomé Bennassar, Valladolid en el siglo del oro (Valladolid, 1989), 178-9.

29. See, for example, AHN, Clero, leg. 7804,7847, 7906, 7910. This was even true of reformed convents that had been founded with the purpose of rejecting monastic wealth. By the late-sixteenth century the convent of the discalced Carmelites, for example, required a dowry of 1000 ducados which easily put it in league with older Cistercian houses in the city; AHN, Clero, leg. 7820.

30. For a fuller explication of the factors and circumstances that had allowed convents to cultivate this type of identity see Elizabeth A. Lehfeldt, "Sacred and Secular Spaces: Religious Women in Golden-Age Valladolid," PhD diss, Indiana University, 1996. 
31. In addition to the case of Santa María de las Huelgas outlined below, see the case of Santa Clara in Valladolid. A wealth of royal privileges entitled the community to the annual collection of over 80,000 maravedís and 80 cargas of wheat.

32. Convent account books provide evidence of these types of "installment" payments; see, for example, AHN, Clero, Libro 17501.

33. AHN, Clero, leg. 7847.

34. AHN, Clero, leg. 7810.

35. AHN, Clero, leg. 7803.

36. See Beceiro Pita and Córdoba de la Llave, Parentesco, 237.

37. AHN, Clero, Libro 17275.

38. AHN, Clero, leg. 7804.

39. AHN, Clero, Libro 17265.

40. AHN, Clero, Libro 17020.

41. Beceiro Pita and Córdoba de la Llave, Parentesco, 244

42. lbid.

43. lbid., 246.

44. This provision was based on Antonio Gómez' sixteenth-century commentary on the Leyes de Toro, cited in Clavero, Mayorazgo, 231. See also a discussion of alienating mayorazgos to meet the legal requirements of returning a widow's dowry to her upon her husband's death; Beceiro Pita and Córdoba de la Llave, Parentesco, 237.

45. AHN, Clero, Libro 17275.

46. AHN, Clero, Libro 17285.

47. AHN, Clero, leg. 7794.

48. AHN, Clero, leg. 7847.

49. Some of the details of these disputes can be pieced together with records in $A H N$, Clero, leg. 7847

50. AHN, Clero, leg. 7847.

51. Ibid.

52. lbid.

53. In 1568 María de Abreo had authorized Pedro Salgado to collect the debts owed to her husband's estate; AHN, Clero, leg. 7847.

54. Ibid.

55. Ibid. 
56. lbid.

57. AHN, Clero, leg. 7802 and Libro 17021.

58. AHN, Clero, leg. 7847.

59. AHN, Clero, Libro 17175.

60. AHN, Clero, leg. 7847.

61. Ibid.

62. Kagan, Lawsuits, 39.

63. Beceiro Pita and Córdoba de la Llave, Parentesco, 35-107. Simon Barton, The Aristocracy in Twelfth-Century León and Castile (Cambridge, 1997), 42-6.

64. Beceiro Pita and Córdoba de la Llave, Parentesco, 234.

65. Ibid., 232.

66. Ibid., 234.

67. Ibid. As early as the late-fourteenth century Pedro González de Mendoza feared that any partitioning of the mayorazgo he and his wife were creating would lead to the lessening and perishing of the lineage. Quoted in Ibid.

68. For this trend in Valladolid see Adeline Rucquoi, Valladolid en la Edad Media, vol. 1 (Valladolid, 1989), 320-1, 324-6.

69. See the examples offered by James S. Amelang, Honored Citizens of Barcelona: $\mathrm{Pa}$ trician Culture and Class Relations, 1490-1714 (Princeton, 1986).

70. This has been powerfully demonstrated in Bilinkoff, Avila of Saint Teresa.

71. For the social conflict between these two groups see, for example, Henry Kamen, Spain 1469-1714: a Society of Conflict (London, 1988), 103-11; George Huppert, After the Black Death: A Social History of Early Modem Europe (Bloomington, IN, 1986); Bilinkoff, Avila of Saint Teresa , 62-77.

72. AHN, Clero, leg. 7803.

73. This story is recounted in Sangrador y Vitores, Historia, vol. 2, 313.

74. I have found only one case that was tried in an ecclesiastical court.

75. Kagan, Lawsuits, 33-4.

76. This despite the insistence of the ecclesiastical courts that these cases were within their purview; see Kagan, Lawsuits, 34.

77. Martín González and Javier de la Plaza Santiago, Monumentos, 109-30.

78. AHN, Clero, Libro 17283.

79. AHN, Clero, leg. 7904.

80. AHN, Clero, leg. 7907. 
81. AHN, Clero, Libro 17285.

82. AHN, Clero, leg. 7907.

83. AHN, Clero, leg. 7910.

84. Ibid.

85. AHN, Clero, leg. 7803. How Inés intended to pay for this is not clear. The source of this income may have been the result of a dispute the convent entered into on her behalf in 1599 in which lnés claimed the rights to a portion of her maternal legítimas. See AHN, Clero, leg. 7804. 